\title{
Front Matter: Volume 12067
}

, "Front Matter: Volume 12067," Proc. SPIE 12067, AOPC 2021: Biomedical Optics, 1206701 (24 November 2021); doi: 10.1117/12.2622814

SPIE. Event: Applied Optics and Photonics China 2021, 2021, Beijing, China 


\title{
PROCEEDINGS OF SPIE
}

\section{AOPC 2021: Biomedical Optics}

\author{
Xunbin Wei \\ Liwei Liu \\ Editors
}

20-22 June 2021

Beijing, China

Organized by

University of Electronic Science and Technology of China (China)

Science and Technology on Low-light-level Night Vision Laboratory (China)

Science and Technology on Electro-Optical Information Security Control (China)

Nano-Optoelectronics Laboratory, Department of Electronic Engineering, Tsinghua University (China)

Sponsored by

Chinese Society for Optical Engineering (China)

Published by

SPIE 
The papers in this volume were part of the technical conference cited on the cover and title page. Papers were selected and subject to review by the editors and conference program committee. Some conference presentations may not be available for publication. Additional papers and presentation recordings may be available online in the SPIE Digital Library at SPIEDigitalLibrary.org.

The papers reflect the work and thoughts of the authors and are published herein as submitted. The publisher is not responsible for the validity of the information or for any outcomes resulting from reliance thereon.

Please use the following format to cite material from these proceedings:

Author(s), "Title of Paper," in AOPC 2021: Biomedical Optics, edited by Xunbin Wei, Liwei Liu, Proc. of SPIE 12067, Seven-digit Article CID Number (DD/MM/YYYY); (DOI URL).

ISSN: 0277-786X

ISSN: 1996-756X (electronic)

ISBN: 9781510650091

ISBN: 9781510650107 (electronic)

Published by

SPIE

P.O. Box 10, Bellingham, Washington 98227-0010 USA

Telephone +1 3606763290 (Pacific Time)

SPIE.org

Copyright (C) 2021 Society of Photo-Optical Instrumentation Engineers (SPIE).

Copying of material in this book for internal or personal use, or for the internal or personal use of specific clients, beyond the fair use provisions granted by the U.S. Copyright Law is authorized by SPIE subject to payment of fees. To obtain permission to use and share articles in this volume, visit Copyright Clearance Center at copyright.com. Other copying for republication, resale, advertising or promotion, or any form of systematic or multiple reproduction of any material in this book is prohibited except with permission in writing from the publisher.

Printed in the United States of America by Curran Associates, Inc., under license from SPIE.

Publication of record for individual papers is online in the SPIE Digital Library.

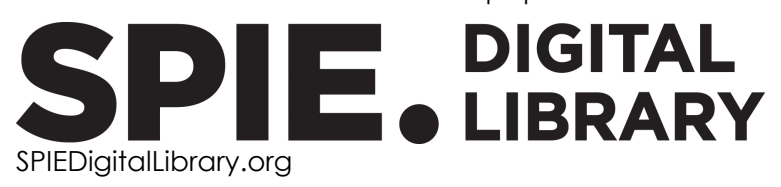

Paper Numbering: A unique citation identifier (CID) number is assigned to each article in the Proceedings of SPIE at the time of publication. Utilization of CIDs allows articles to be fully citable as soon as they are published online, and connects the same identifier to all online and print versions of the publication. SPIE uses a seven-digit CID article numbering system structured as follows:

- The first five digits correspond to the SPIE volume number.

- The last two digits indicate publication order within the volume using a Base 36 numbering system employing both numerals and letters. These two-number sets start with 00, 01, 02, 03, 04, 05, 06, 07, 08, 09, OA, OB ... 0Z, followed by 10-1Z, 20-2Z, etc. The CID Number appears on each page of the manuscript. 


\section{Contents}

\section{BIOMEDICAL OPTICS}

1206702 Discrimination and classification of true or mock blood based on photoacoustic spectroscopy combined with support vector machine [12067-4]

1206703 Design simulation and application of integrated microarray chip based on polymerase chain reaction [12067-5]

1206704 Study on the influence of incubation temperature on specific protein detection results based on COMSOL simulation [12067-6]

1206705 Conformational analysis of soluble amyloid $\beta$-peptide using Fourier transform infrared spectroscopy with transmission mode [12067-7]

1206706 Single cell detection using self-mixing interferometry based on microfluidic chip [12067-8]

$1206707 \quad$ Fabrication of biological detection chip based polymer nanostructures via nanoimprint lithography [12067-10]

1206708 Application of serum infrared spectroscopy combined with ensemble learning method in rapid diagnosis of cervical lesions [12067-17]

1206709 Label-free multiphoton imaging to detect hepatic steatosis in chronic liver disease [12067-19]

12067 OA Rapid diagnosis and classification of cervical lesions by serum infrared spectroscopy combined with machine learning [12067-20]

12067 OB A new near-infrared excitation PDT photosensitizer in vivo [12067-23]

12067 OC Visualization of the important components in fumor microenvironment of breast cancer using multiphoton microscopy [12067-24]

12067 OD Research on eye axial length measurement system based on Twyman-Green interferometer combined with digital signal processing [12067-25]

12067 OE The optical thin film filters applied in bioscience [12067-27]

12067 OF Effects of phototherapy on memory and BDNF/TrkB signaling pathway in sleep-deprived mice [12067-34]

12067 0G Quantification of tissue blood flow and scattering coefficient by diffusion correlation spectroscopy [12067-37]

$12067 \mathrm{OH}$ Defocusing effects on label-free cervical cancer cell classification by two-dimensional light scattering static cytometry and machine learning [12067-39] 
Proc. of SPIE Vol. 12067 1206701-4

Downloaded From: https://www.spiedigitallibrary.org/conference-proceedings-of-spie on 26 Apr 2023 Terms of Use: https://www.spiedigitallibrary.org/terms-of-use 